\title{
Estudo bibliométrico e epistemológico das teses de doutorado do PPGE-UFSCAR (1993-2005)
}

Márcio Coelho

Doutor em Educação pela UFSCar

Maria Cristina Piumbato Innocentini Hayashi

Professora Associada da UFSCar

\section{Resumo}

Considerando as mudanças que ocorreram no contexto histórico-social e também na pesquisa em Educação no Brasil a partir da década de 1990, este estudo analisou a produção científica do PPGE-UFSCar, tendo como objeto 55 teses defendidas na Área de Fundamentos da Educação, entre 1993 e 2007, submetidas à análise bibliométrica e epistemológica, objetivando determinar qual o paradigma foi predominante no período. $O$ resultado revelou que o Marxismo foi utilizado em mais de 60\% das pesquisas; e também identificou a presença de tendências pós-modernas fundamentando 17 teses e da Fenomenologia em 3 teses.

Palavras-chave: Pesquisa educacional; Análise bibliométrica; Análise epistemológica.

\begin{abstract}
Considering the changes that occurred in the socio-historical context and also in research on education in Brazil from the 1990s, this study examined the scientific production of PPGE-UFSCAR, having as object 55 theses in the area of Foundations of Education, between 1993 and 2007 submitted to bibliometric and epistemological analysis, to determine which paradigm was predominated in the period. The result revealed that Marxism has been used in over $60 \%$ of researches, and also identified the presence of post-modern trends basing 17 theses and of the Phenomenology in 3 theses.
\end{abstract}

Keywords: Educational research; bibliometric analysis; epistemological analysis. 


\section{Introdução}

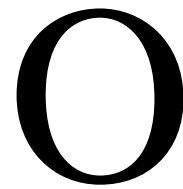

crescimento da produtividade científica e o consequente aumento da literatura científica tem gerado a necessidade de procedimentos capazes de auxiliar na seleção e análise desse material publicado. Atendendo a essa necessidade a meta-análise desponta como uma atividade científica que reúne e avalia a literatura científica por meio de análises estatísticas, apresentando de forma sintética a complexidade dessa produção. A meta-análise transcende análises já realizadas, assumindo sobre elas uma postura crítica, indo além da simples revisão bibliográfica por combinar técnicas quantitativas e qualitativas.

Inserindo-se nesse empenho acadêmico de meta-análise, este estudo teve por objetivo central realizar a análise bibliométrica e epistemológica da produção científica do Programa de Pós-Graduação em Educação (PPGE) da Universidade Federal de São Carlos (UFSCar), para determinar qual o paradigma epistemológico predominante e, destarte, explicitar a relação entre esta produção científica e o contexto mais amplo. Para tal explicitação, o paradigma epistemológico assumido foi o marxismo, por compreender a realidade de forma dinâmica, em suas múltiplas determinações, a partir das relações sociais de produção, tendo em vista a superação de todas as formas sociais de exploração, para qual propósito todo conhecimento pode e deve contribuir.

O recorte empírico do objeto delimitou a pesquisa à análise da produção científica do curso de Doutorado do PPGE-UFSCar, especificamente da Área de Concentração em Fundamentos da Educação, por esta oferecer com maior clareza os dados para a explicitação dos paradigmas epistemológicos. A delimitação do período pesquisado considerou a especificidade histórica da década de 1990 e início do século XXI, circunscrevendo a coleta de dados a partir da primeira tese defendida em 1993, seguindo um ciclo de quinze anos, até 2007 , o que abrangeu um total de 57 teses.

Os dados da pesquisa foram coletados nas seguintes fontes: primordialmente nas teses selecionadas, sendo complementados por informações obtidas no Banco de Teses e no Caderno de Indicadores da 
CAPES; nos curricula da Plataforma Lattes, tanto dos doutorandos quanto dos orientadores; e em questionários respondidos pelos docentes orientadores, complementados pela análise de suas principais publicações, livros e artigos.

Tendo em vista a análise bibliométrica e epistemológica, foram elaborados dois formulários para a coleta de dados, denominados de Matriz Bibliométrica e Epistemológica e de Matriz de Referências. A primeira Matriz contendo dados sobre o autor e o orientador (nome, gênero, data do ingresso e defesa, formação na graduação e pós-graduação, agência de fomento) e sobre a tese (título, linha de pesquisa, resumo e palavras-chave), e dados epistemológicos. Estes tiveram como referência o instrumento de análise construído por Sánchez Gamboa (2012, p. 75), explicitados nos níveis técnico-instrumental, metodológico, teórico, epistemológico, e nos pressupostos gnosiológicos e ontológicos. A estes foi acrescentado o nível ético, fundamentado nas afirmações de Marx de que a resolução de contradições teóricas ocorre por meios práticos (2004) e de que é preciso não somente interpretar, mas transformar o mundo (1978), e também em Habermas (1980) sobre o interesse do conhecimento crítico; este nível tem o intuito de verificar se os autores explicitaram a incidência de sua pesquisa na efetiva transformação da realidade.

Na Matriz de Referências foram registradas as seguintes informações sobre as obras citadas nas teses: o tipo de publicação, a quantidade de vezes em que a obra foi citada, a utilização da obra para fundamentar o referencial teórico, a confirmação ou crítica da teoria citada, uso da obra na interpretação dos dados ou na conclusão, e a temática da citação.

Finalmente, o questionário enviado aos docentes orientadores, com sete questões abertas diretivas e uma não-diretiva, buscando detectar o referencial teórico do orientador, a relação com a escolha do referencial teórico do orientando, e informações sobre o PPGE-UFSCar. 


\section{Notas históricas sobre a pesquisa educacional no Brasil}

O presente estudo sobre a produção científica versa especificamente sobre a pesquisa em Educação no Brasil, a qual chega ao século XXI consolidada, resultado de um processo histórico que contou com iniciativas esparsas no início do período republicano, encontrou um importante impulso com a criação do INEP e foi institucionalizada pelos programas de pós-graduação.

O propósito de realizar estudos sobre a realidade educacional brasileira, segundo Lourenço Filho (1964), já existia no período imperial, e foi aprimorado com a criação do Pedagogium, em 1890, e em 1911, do Conselho Superior de Ensino. No contexto das reformas do governo Vargas foi criado em 1936, o Instituto Nacional de Pedagogia, para promover pesquisas sobre as questões educacionais do país, sendo instalado somente em 1938, já com o nome de Instituto Nacional de Estudos Pedagógicos. Para Fernando de Azevedo as raízes da criação do INEP podem ser encontradas no movimento de ideias e reformas que aconteceram entre 1926 e 1935, considerado por ele "um dos períodos mais agitados e fecundos da história da educação e cultura do país." (1964, p. 18).

Em seus primeiros anos, sob a direção de Lourenço Filho, o INEP dedicou-se a realizar um levantamento bibliográfico sobre a questão educacional e organizar um ementário da legislação na área. Em 1941 foi criada a Revista Brasileira de Estudos Pedagógicos (RBEP) para divulgar os estudos do Instituto, que nesse período inicial e até meados de 1950, foram de natureza psicopedagógica. O segundo período histórico do INEP vai de 1952, quando Anísio Teixeira assume a direção, até o golpe militar de 1964. Nesse período foram lançadas a Campanha do Livro Didático e Manuais de Ensino (CALDEME) e a Campanha de Inquéritos e Levantamentos do Ensino Médio e Elementar (CILEME), articuladas pelo Centro de Documentação Pedagógica, criado em 1953. Este foi o germe do Centro Brasileiro de Pesquisas Educacionais (CBPE), criado em 1955, juntamente com os Centros Regionais de Pesquisa, que ampliaram as ações do INEP promovendo estudos regionais dos problemas educacionais e favorecendo intervenções nessas realidades e na política educacional nacional. Nesse 
período têm início as pesquisas de caráter sociológico na Educação. O regime militar impôs modificações na estrutura do INEP, gerando um contínuo esvaziamento até 1985, quando se tornou um órgão de assessoria do Ministério da Educação, não tendo atuação na área de pesquisa, a qual já havia sido absorvida pelos programas de pós-graduação.

A pós-graduação, por sua vez, tem sua gênese no Brasil, segundo Sucupira (1980, p. 3ss), com o Estatuto das Universidades Brasileiras, o qual previa o doutoramento no modelo europeu. O termo pós-graduação, enquanto grau do ensino superior, foi citado em um documento legal pela primeira vez no Estatuto da Universidade do Brasil (Decreto-Lei no 21.321 junho/1946). Foi na Universidade de Brasília, criada em 1961, que a pósgraduação tornou-se uma atividade institucional, vindo a ser organizada enquanto nível de ensino superior em 1965, com o Parecer 977 (Parecer Sucupira). Nessa data, segundo dados da CAPES, havia no país 27 cursos classificados no nível de mestrado e 11 no de doutorado.

Tal Parecer foi solicitado ao Conselho Federal de Educação (CFE) pelo Ministro da Educação e Cultura, Flávio Suplicy de Lacerda, que apresentava três motivos fundamentais para a implantação da pósgraduação: formar professorado, estimular a pesquisa científica e assegurar treinamento para técnicos e trabalhadores intelectuais (cf. BRASIL, 1975, p. 130). Entre os princípios fundamentais apresentados no Parecer estão a estruturação da pós-graduação stricto sensu no nível de mestrado e doutorado, flexibilidade na definição de currículo e conteúdos e exigência de uma dissertação, para o mestrado ou tese, para o doutorado. Segundo Saviani (2008, p. 310), o modelo assumido foi o norte-americano quanto ao processo de formação, mas conservou influência do modelo europeu ao exigir o trabalho teórico do aluno.

A implantação da pós-graduação foi processual, com a normatização do credenciamento de cursos, pelo Parecer 77/1969 do CFE, a criação dos Centros Regionais de Pós-Graduação, e por fim a criação do Conselho Nacional de Pós-Graduação, em 1974, que geriu a pós-graduação até 1982, quando tal função foi assumida pela CAPES. Para orientar tal processo, que inicialmente fora espontâneo (cf. BRASIL, I PNPG, p. 142), o Conselho 
Nacional de Pós-Graduação elaborou o I Plano Nacional de Pós-Graduação, que vigorou até 1982, quando foi substituído pelo II PNPG, já sob a responsabilidade da CAPES. O III PNPG foi lançado em 1986, já no período de redemocratização, vigorando até 1989. O novo Plano só foi articulado a partir de 1996, mas não chegou a ser publicado, vindo a CAPES publicar o PNPG 2005-2010, sendo este substituído pelo Plano em vigor, para o período de 2011-2020.

No período inicial, sob a ditadura militar, com sua política desenvolvimentista, predominavam pesquisas que abordavam a educação de forma economicista, inspiradas pela Teoria do Capital Humano. A partir da crise do "milagre econômico", na década de 1970 e no contexto de resistência à ditadura militar, as teorias que favoreciam a crítica social, especialmente as marxistas, exerceram hegemonia na produção da pósgraduação.

\section{O contexto histórico-social da produção científica}

O período histórico no qual está circunscrita a produção científica analisada, entre o final do séc. XX e início do séc. XXI, apresenta características peculiares. Segundo Hobsbawm (2009), o "breve século XX" terminou em 1991, com o fim da União Soviética, e seu último período (1973-1991), chamado de "o desmoronamento" foi marcado pela diminuição do poder dos Estados nacionais, dentro do processo de globalização, pela queda do bloco socialista e pelo desenvolvimento tecnológico, especialmente da informação.

A década de 1990, segundo Hobsbawm (2009), configurou-se como um período de crises em nível global, seja na economia com problemas como desemprego e desigualdade social, na política com pressão de grupos infranacionais enfraquecendo as estruturas nacionais, e também a crise ideológica. Esta, não apenas atingiu a teoria marxista, por causa do esfacelamento do comunismo no leste europeu, mas abrangeu todas as crenças que fundamentavam a cultura modera, "uma crise das teorias 
racionalistas e humanistas abraçadas tanto pelo capitalismo liberal como pelo comunismo" (HOBSBAWM, 2009, p. 20).

Essa crise das teorias é compreendida por alguns teóricos como crise da modernidade (HABERMAS, 1992), e por outros como a instauração da pós-modernidade. A proposta pós-moderna assenta-se sob o niilismo e perspectivismo de Nietzsche, mesclando o pragmatismo e o pósestruturalismo, com o intuito de rejeitar todas as orientações do Iluminismo. De modo especial, prevalece a fragmentação e a desconfiança perante todos os discursos que pretendem ser universais, rejeitando toda forma de metanarrativa, como defende Lyotard: "O grande relato perdeu sua credibilidade, seja qual for o modo de unificação que lhe é conferido: relato especulativo, relato de emancipação.” (1993, p. 69)

Essa rejeição às metanarrativas, associada ao desencanto com a teoria marxista após as mudanças políticas no leste europeu, influenciaram a produção científica. Especificamente na pesquisa em Educação, gerou o que Kuenzer e Moraes (2005) denominam de "recuo da teoria" marcado por um sincretismo teórico e metodológico. Já Gatti (2001) aponta um pragmatismo nas pesquisas, o qual gera um empobrecimento teórico, seja pela inconsistência teórica na fundamentação das pesquisas, seja pela utilização de teorias apreendidas de forma simplista em "modismos teóricos".

\section{O objeto da pesquisa}

A produção científica analisada está situada dentro de um contexto político e educacional específico, que inclui a criação da Universidade Federal de São Carlos (UFSCar) e o Programa de Pós-Graduação em Educação. A instalação da UFSCar foi resultado da articulação de políticos locais e estaduais, e correspondeu ao projeto do governo militar, o qual compreendia a educação como pressuposto do desenvolvimento econômico. A universidade iniciou suas atividades em 1970, com os cursos de Licenciatura em Ciências e de Engenharia de Materiais e, em 1976, deu início à pós-graduação com os cursos de mestrado e doutorado em Ecologia e Recursos Naturais, e o curso de mestrado em Educação. 
O mestrado em Educação foi marcado pelo pioneirismo e pela inovação. Já em 1974, o Prof. Dermeval Saviani aceitara o convite para a implantação do Programa de Pós-Graduação em Educação, contando também com um convênio com Fundação Carlos Chagas, a qual, além do apoio técnico-administrativo, cedeu pesquisadores para o quadro docente e, principalmente, sua experiência em pesquisa educacional. A proposta era de criar um programa novo, tanto na estrutura quanto no funcionamento. Em vista disso, dois aspectos foram considerados fundamentais: o objetivo, de formar o pesquisador em Educação como um profissional especializado e a organização do plano curricular, que conciliava uniformidade com diversidade, permitindo ao aluno compor seu currículo, combinando módulos. (cf. SAVIANI; GOLDBERG, 1976)

Inicialmente, o PPGE possuía duas Áreas de Concentração, Planejamento de Ensino e Pesquisa Educacional, sendo a primeira substituída pela de Metodologia de Ensino, que a partir de 2008 passou a ser denominada como Processos de Ensino e de Aprendizagem; e em 1985, a segunda tornou-se a Área de Fundamentos da Educação. Em 2010, o PPGE passou a contar com uma única Área de Concentração em Educação, com sete linhas de pesquisa.

O curso de Doutorado, criado em 1991, alicerçava-se na qualidade crescente do curso de Mestrado e propunha-se a estreitar os vínculos entre a realidade local e contexto educacional brasileiro. Na Área de Concentração em Fundamentos da Educação, a proposta era de analisar o ato pedagógico na sua historicidade, ou seja, em sua relação com a prática social (cf. UFSCarCECH-PPGE, 1990). Em sua criação o Doutorado na área de Fundamentos contava com sete docentes, em três linhas de pesquisa: Educação e Trabalho, Educação Brasileira Contemporânea, e Fundamentos da Educação. De seu início até 2006, ingressaram 242 alunos no Doutorado (cf. PPGE-UFSCar, 2007, p. 43), e até o ano de 2007, ocorreram 148 defesas, sendo 94 da área de Metodologia de Ensino e 54 de Fundamentos da Educação. 


\section{Resultados da pesquisa}

\subsection{A Análise bibliométrica}

A análise bibliométrica foi realizada inicialmente considerando o número de alunos ingressantes no Curso de Doutorado em cada ano, nas duas Áreas de Concentração, de Metodologia de Ensino e de Fundamentos da Educação, como indica a Figura 1:

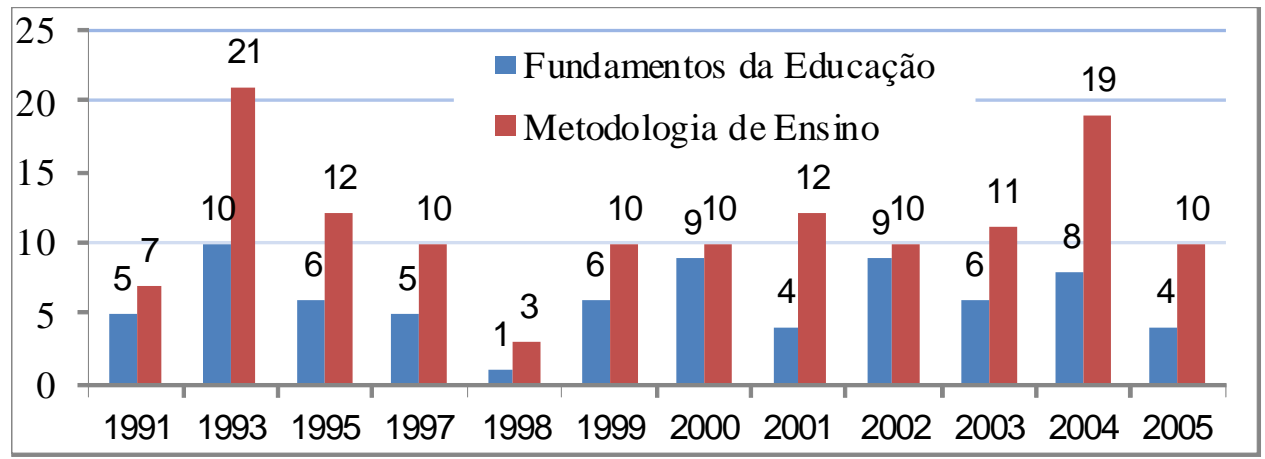

Figura 1 - Alunos ingressantes no Curso de Doutorado no período 1991-2005 Fonte: Secretaria do PPGE-UFSCar

Os dados revelam que na área de Metodologia de Ensino houve um ingresso maior de alunos. Nos anos 1992, 1994 e 1996 não houve ingresso porque nos primeiros anos do Curso a seleção era realizada a cada dois anos. Em 1993 houve um grande número de ingressos, devido a um convênio com a Universidade de Caxias do Sul-RS, quando ingressaram 10 alunos, todos na Área de Metodologia de Ensino.

$\mathrm{Na}$ área de Fundamentos da Educação ingressaram 73 alunos, com uma média de 4 a 6 alunos ingressantes por ano, tendo uma elevação no segundo ano do curso, nos anos 2000, 2002 e 2004, como mostra a Figura 1. Dos 73 ingressantes, cinco alunos não concluíram o curso, representando uma desistência de quase 7\%. Entre os ingressantes até 2005, 8 defenderam no ano de 2008 e 1, em 2009, ficando fora do período delimitado da pesquisa. Assim, excluindo os inconclusos e os que defenderam depois de 2007, a produção científica entre 1993 e 2007 foi de 57 teses defendidas, como mostra a Figura 2. 


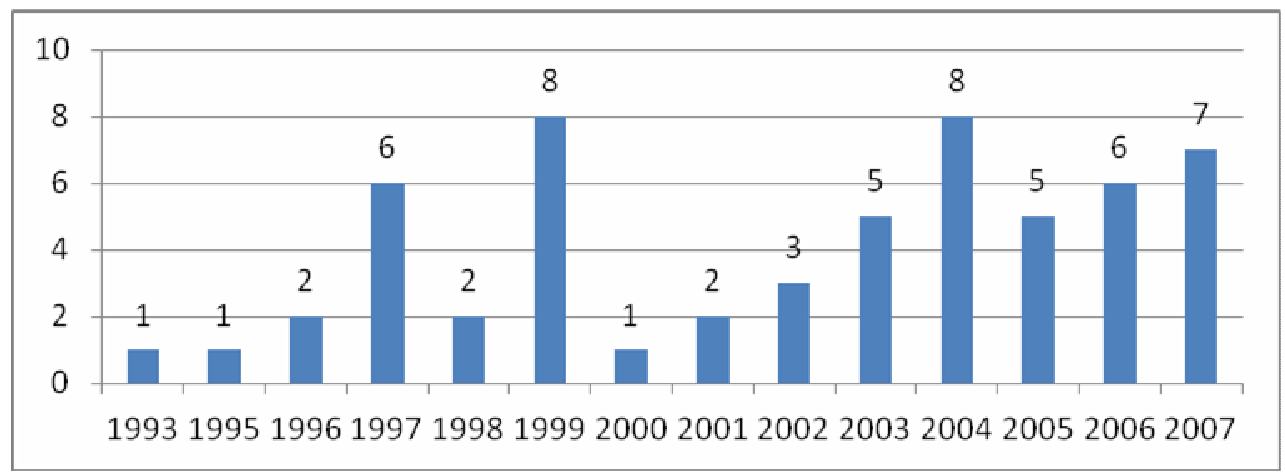

Figura 2 - Distribuição das teses defendidas na Área de Fundamentos da Educação do PPGE/UFSCar no período 1993-2007

Fonte: Secretaria do PPGE-UFSCar

Fazendo uma divisão equitativa do período estudado, é possível verificar que nos cinco primeiros anos de produção do PPGE (1993 a 1997) foram defendidas 10 teses, nos cinco anos seguintes (1998 a 2002) foram 15 teses e nos últimos cinco anos abrangidos pela pesquisa (2003 a 2007) 31 teses foram defendidas. Tais dados indicam um crescimento gradativo no número de defesas e um número similar de teses defendidas a cada ano, atestando a consolidação do PPGE-UFSCar enquanto agência de produção científica.

Com relação ao corpo docente os dados indicaram que 13 docentes atuaram no PPGE/UFSCar entre 1993 e 2007, sendo quatro mulheres (Betty Oliveira, Ester Buffa, Maria Alice Mesquita e Marisa Bittar) e nove homens (Bruno Pucci, Valdemar Sguissardi, Ramon Peña Castro, Paolo Nosella, Joaquim Gonçalves Barbosa, Potiguara Acácio Pereira, Amarílio Ferreira Júnior, João dos Reis Silva Júnior e Antônio Álvaro Soares Zuin). Relacionando o número de orientações com o gênero do docente, verifica-se que as mulheres orientaram 20 teses, o que representa $35 \%$ da produção, enquanto que os homens orientaram 37 teses, equivalente a $65 \%$. Na média de teses orientadas em cada gênero, percebe-se pouca diferença, tendo as mulheres uma média de cinco teses por docente, e os homens, pouco mais de quatro teses por docente.

Dois docentes, Paolo Nosella e Ester Buffa, tiveram presença preponderante, orientando 37\% das teses. Ao lado de Ramon Peña Castro, Bruno Pucci, Betty Oliveira e Valdemar Sguissardi, esses docentes 
compuseram o núcleo estruturante e fundador do doutorado no PPGE/UFSCar. Com a aposentadoria de Betty Oliveira e Valdemar Sguissardi, a segunda geração de orientadores, composta por Joaquim Gonçalves Barbosa, Maria Alice Nogueira, Potiguara Pereira e Marisa Bittar, formam o grupo de pesquisadores responsável pela implementação e expansão do doutorado do PPGE/UFSCar. Com o fim da vinculação de Joaquim Barbosa, Maria Alice Nogueira e Potiguara Pereira ao Programa, coube a Marisa Bittar, Ester Buffa e Paolo Nosella consolidarem o doutorado e receberem os docentes que constituirão a terceira geração de docentes orientadores, entre eles Amarílio Ferreira Júnior, Antônio Álvaro Soares Zuin e João dos Reis Silva Júnior, que iniciaram suas orientações em 2002.

A partir da consulta ao curriculum na Plataforma Lattes identificou-se que, entre os 57 doutores formados no PPGE/UFSCar, 26 (46\%) fizeram sua graduação em Pedagogia, 5 (9\%) em Letras, 5 (9\%) em Psicologia, 3 (5\%) em Serviço Social, 3 (5\%) em Filosofia, 3 (5\%) em História, 3 (5\%) em Direito, 2 (3,5\%) em Ciências Sociais, 2 (3,5\%) em Educação Física. Os demais (9\%) são formados em Desenho e Plástica, Estudos Sociais, Matemática, Música e Engenharia de Materiais. Embora um grande número tenha cursado Pedagogia, a maioria é formada em outras áreas, sendo quase todas pertencentes à grande área das Ciências Humanas. Considerando que a Área de Concentração pesquisada é de Fundamentos da Educação, percebese um número pequeno de graduados em História, Filosofia e Sociologia e nenhum na área de Economia. Os cursos nas quais os doutorandos fizeram sua graduação podem ser visualizados na Figura 3.

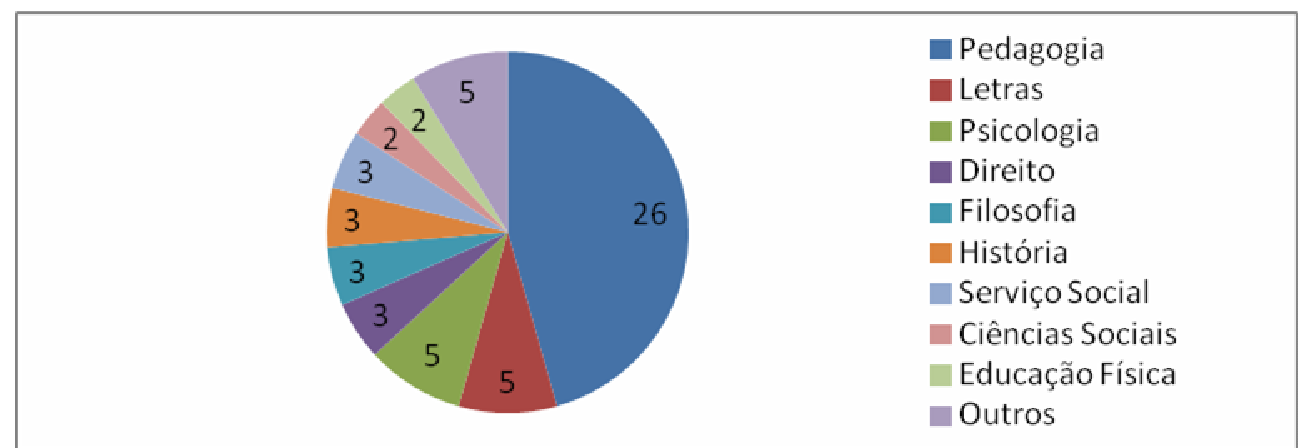

Figura 3 - Formação dos doutorandos (Graduação)

Fonte: Plataforma Lattes 
Com relação à formação na pós-graduação, ou seja no curso de Mestrado, a grande maioria, 45 (79\%) dos doutorandos são Mestres em Educação. A presença de mestres em outras áreas (Filosofia, Sociologia, Letras, Serviço Social, Antropologia, Direito, Extensão Rural), apesar de constituírem pouco mais que um quinto dos doutorandos (21\%), revela a abertura do PPGE para o diálogo com outras áreas do saber.

Observando instituição superior onde os candidatos cursaram o Mestrado, constata-se a abertura do PPGE para candidatos oriundos de outras instituições, pois menos da metade, ou seja, somente 23 doutorandos obtiveram seu Mestrado na UFSCar. E quanto à região onde cursaram a pósgraduação, verificou-se que apenas 37 doutorandos o fizeram no Estado de São Paulo; seis alunos vieram de outros de outros Estados da região Sudeste, oito da região Nordeste, três do Sul e três do Centro-Oeste. Isso revela a abertura do PPGE para outras instituições e a abrangência de sua ação formativa, por não se restringir à própria região, e igualmente a diversidade cultural de seu quadro discente.

Quanto a atuação profissional dos doutores formados pelo PPGEUFSCar, todos atuam ou atuaram, pois alguns já estão aposentados, no ensino superior, sendo 56 na atividade docente e um como técnico administrativo, em 33 IES diferentes. As que agregam um maior número são a UNESP (nove doutores) em cinco campi diferentes, seguida da UFSCAr (sete doutores), e a USP e a UNIOSTE (com dois doutores cada). Apesar da maioria dos doutores formados pelo PPGE, num total de 23, atuarem no Estado de São Paulo, os demais estão distribuídos equitativamente nas demais regiões do país, revelando que o Programa exerce um papel importante na formação de docentes para as instituições de ensino superior de todo o país.

\subsection{Análise epistemológica}

A análise epistemológica foi realizada a partir de dados coletados de 55 teses, pois duas teses, defendidas em 1997 e 2006, não tiveram o volume depositado, nem no arquivo do PPGE-UFSCar e nem na Biblioteca da Universidade, e seus autores não forneceram cópia. 
Inicialmente serão apresentados os dados referentes ao nível teórico da Matriz Paradigmática (SÁNCHEZ GAMBOA, 2012, p. 79), enfatizando a questão do referencial teórico, por ser o foco principal desta pesquisa. Os demais dados registrados na Matriz Bibliométrica e Epistemológica, serão apresentados de forma comparativa entre os três paradigmas epistemológicos identificados na produção científica.

\subsubsection{A explicitação do referencial teórico nas teses}

Entre as 55 teses analisadas, 38 explicitaram o referencial teórico utilizado, representando $70 \%$ da produção científica do período, e as demais 17 teses apenas indicaram as categorias teóricas utilizadas ou os autores nos quais foi buscada a base teórica para a compreensão dos objetos estudados. Isso demonstra que a maioria dos autores adequou-se à proposta do Programa, de valorizar os fundamentos teóricos na pesquisa em Educação, fazendo jus à característica específica da área de Fundamentos da Educação. Entretanto, chama a atenção o fato de que um número considerável de teses, representando $30 \%$ da produção científica, não assumiram nenhum referencial teórico.

\subsubsection{Categorização das teses a partir do paradigma epistemológico}

Tomando como referência as afirmações de Habermas (1980) e de Demo (2009) sobre a produção do conhecimento e os estudos de Goergen (1981), Nossela e Buffa (2009), Sanchéz Gamboa (2012) e Lima (2003), especificamente sobre a fundamentação teórica da pesquisa em Educação, delimitamos quatro paradigmas para a classificação da produção científica analisada, a saber: o Positivismo, a Fenomenologia, o Marxismo e as tendências da pós-modernidade.

Das 55 teses analisadas, 35 utilizaram o Marxismo como referencial teórico, equivalendo a mais de $63 \%$ do total; 17 trabalhos fundamentaram-se nas tendências pós-modernas, representando 31\%; 3 teses, equivalente a pouco mais de 5\%, utilizaram o paradigma da Fenomenologia, e nenhuma tese assumiu a fundamentação teórica do Positivismo. A Figura 4 mostra a divisão entre os diferentes paradigmas: 


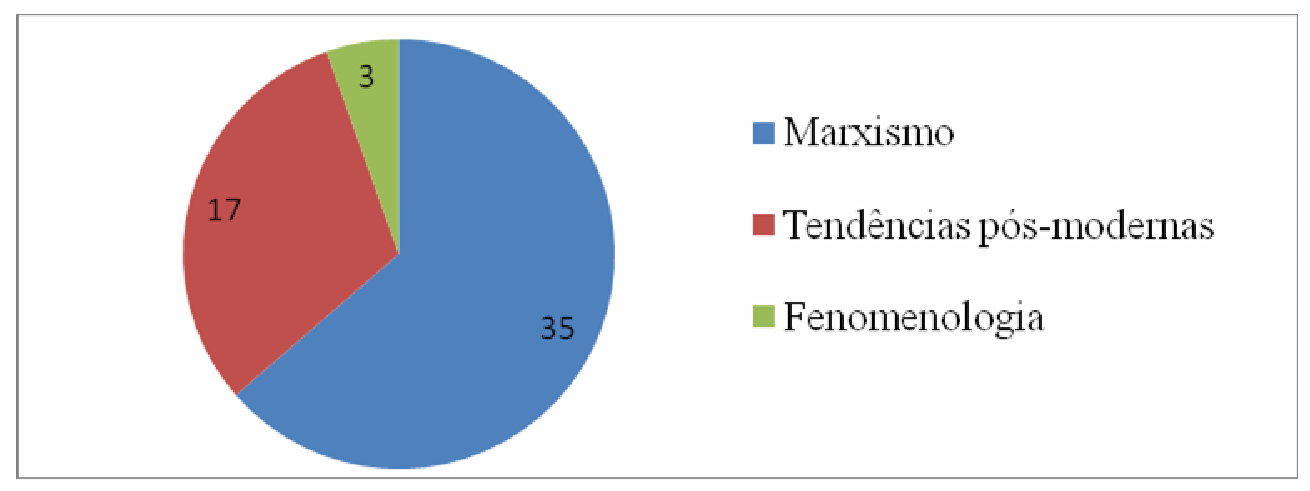

Figura 4 - Distribuição das teses por paradigma epistemológico

A partir das afirmações de Anderson (2004) e Amadeo (2006), que destacam a complexidade histórica e teórica do Marxismo, este não foi considerado como um bloco monomórfico, mas compreendido a partir das suas diferentes nuances teóricas. Destarte, das 35 teses classificadas como marxistas, 11 utilizaram categorias do Marxismo Clássico, especialmente Marx e Engels, 7 teses usaram o pensamento de Gramsci, 4 se fundamentaram em pensadores da Teoria Crítica, 2 buscaram no pensamento de Lukács sua fundamentação, 2 fizeram uso da teoria de Vygotsky e da Psicologia Histórico-social, e 8 foram agrupados separadamente por se fundamentarem em pensadores que não se configuram nesses grupos ou por fazer uso de diferentes vertentes teóricas, mas com uma perspectiva crítica na análise dos dados. No grupo Outros foram incluídos os autores: P. Anderson, Edward P. Thompson, os brasileiros Paulo Freire e Dermeval Saviani, Pierre Bourdieu, Norberto Bobbio. Embora os comentadores não sejam unânimes de que estes últimos sejam marxistas, no conjunto das proposições da pesquisa, o pensamento de tais autores foi utilizado para fundamentar uma concepção crítica. Quando tais autores foram citados sem fundamentar uma concepção crítica, as teses não foram classificadas como marxistas. A Figura 5 mostra a utilização das diferentes nuances teóricas do Marxismo. 


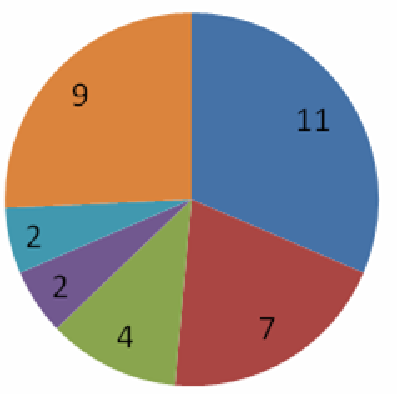

- Marxismo clássico

- Gramsci

Teoria Crítica

Vygotsky

- Lukács

n Outros

Figura 5 - Distribuição das teses que assumiram o Marxismo entre as diferentes nuances teóricas.

Relacionando o ano da defesa com o paradigma utilizado, verifica-se a presença de teses que usaram o Marxismo como referencial teórico em todos os anos do período pesquisado, exceto no ano 2000. Percebe-se um crescimento gradativo do número de teses defendidas com tal referencial nos primeiros anos do Programa, tendo um decréscimo acentuado no início do séc. XXI, e uma retomada do crescimento no final do período desta pesquisa. Quanto às tendências pós-modernas a primeira tese a fundamentar-se nesse paradigma foi defendida em 1997. Se por um lado, podemos afirmar que o PPGE não foi afetado logo em seu início pelo contexto mais amplo, no qual as tendências pós-modernas se faziam presentes, por outro lado, não tardou a receber tais influências, as quais permaneceram até o final do período pesquisado, embora de forma não hegemônica, como indica a Figura 6.

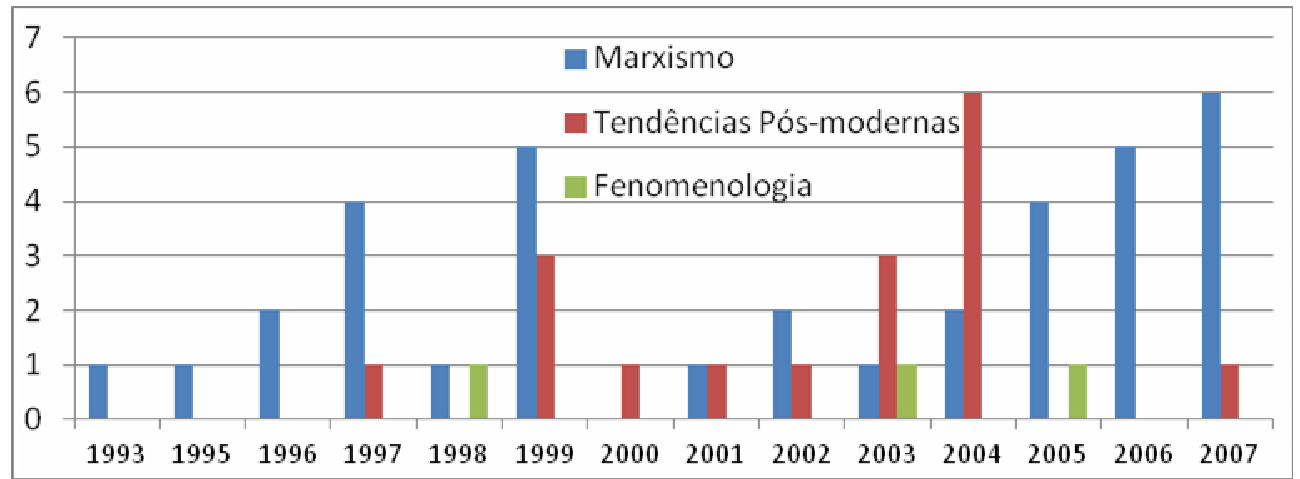

Figura 6 - Distribuição das teses por paradigma epistemológico no período entre 1993 e 2007 
A ausência de teses com referencial teórico positivista e o pequeno número de pesquisas de cunho fenomenológico revela que o PPGE reflete o contexto da pesquisa educacional no Brasil. A partir da década de 1970, no período mais repressivo do regime militar, o Positivismo deixou de ser uma teoria atraente para a produção acadêmica, pela rejeição às suas implicações sociais de submissão à ordem estabelecida. E também a necessidade de um referencial que favorecesse a crítica social, tornou o Marxismo mais pertinente que a teoria fenomenológica.

Porém, como entender a predominância do Marxismo na fundamentação da produção científica do PPGE e, ainda mais, a presença considerável do Marxismo Clássico, em 20\% de todas as teses produzidas no período, dentro do contexto inóspito às categorias marxistas como fora $o$ final do séc. XX? Em primeiro lugar, porque a teoria marxista continua sendo necessária para compreender os mecanismos de opressão, dada a permanência das estruturas de exploração do trabalho e de dominação de classes. Também deve-se ressaltar a reação acadêmica às tendências pósmodernas e a retomada da interpretação da realidade a partir das categorias do marxismo, especialmente o "giro ontológico realista" enquanto reação ao chamado "giro linguístico"1 ${ }^{1}$ E finalmente, conforme dados dos questionários respondidos pelos orientadores, a atuação do docente orientador-pesquisador imprimiu uma característica específica ao PPGEUFSCar, especialmente na resistência às tendências pós-modernas, destacando a inserção do Prof. Paolo Nosella no GT de Trabalho e Educação da ANPEd, e a criação do Grupo do HISTEDBR/Núcleo da UFSCar, em 2004, por iniciativa dos docentes Marisa Bittar, Amarílio Ferreira Jr., Roseli Esquerdo Lopes, Paolo Nosella e Ester Buffa.

\subsubsection{Nível técnico: o tipo de pesquisa, a origem e o tratamento dos dados}

Quanto ao tipo de pesquisa, todas as teses fenomenológicas realizaram pesquisa de cunho empírico-teórica, enquanto as teses pós-modernas apresentaram dez pesquisas do tipo empírico-teórica e sete somente teórica;

1 Sobre a reação ao giro linguístico, ver Sanchéz Gamboa (2011). 
e nas marxista 22 teses realizam pesquisa empírico-teórica e 13 foram unicamente teóricas.

As fontes dos dados empíricos nas teses fenomenológicas foram: histórias de vida, instituições escolares, movimentos populares e produção científica. Nas teses fundamentadas nas tendências pós-modernas as fontes dos dados empíricos foram: história da vida, eventos cotidianos, artesanato, atores e instituições educacionais, trabalhadores, movimentos populares e Grupos de Pesquisa; as fontes teóricas foram Filosofia do Direito, Multirrefencialidade, Complexidade, Cibercultura, Administração Educacional, pensamento de Habermas, de Rousseau, de Lipman, e legislação educacional. Nas pesquisas de fundamentação marxista, as fontes dos dados empíricos foram menos dispersivas, sendo agrupadas em instituições educacionais, realidades do trabalho, documentos históricos e atividades educacionais; já as fontes teóricas foram: literatura marxista, etnomatemática, obras de Saviani, Fórum Nacional de Educação em Defesa da Escola Pública, Teoria Crítica, Filosofia para crianças, neoliberalismo, reformas educacionais, produção científica, Educação de Jovens e Adultos, críticos da reforma educacional brasileira, Pedagogia das Competências, Revista Escola Nova.

Quanto às técnicas utilizadas para a coleta dos dados, nos três grupos de paradigmas foram utilizadas entrevistas do tipo história de vida, entrevistas semi-estruturadas, observação participante, levantamento documental. Nas teses pós-modernas foram também utilizadas: resgate da memória pessoal, fotografias, teste de Associação Livre de Palavras, discursos proferidos em reuniões, levantamento bibliográfico e acesso à internet. Outras técnicas usadas nas teses marxistas foram: questionário socioeconômico, reunião no formato pesquisa-ação, relato de aulas, coleta da produção de alunos, levantamento da produção científica.

Os procedimentos utilizados no tratamento dos dados identificados nos três grupos foram a análise bibliográfica e da produção científica, e análise qualitativa das entrevistas, experiências e questionários. Nas teses pós-modernas também foram utilizados: diálogo entre texto e imagem, uso do software Vantage Point para análise bibliométrica, uso do software Tri- 
Deux Mots para analisar os Testes de Associação de Palavras. E nas pesquisas marxistas aparece ainda a análise de trajetória, análise das narrativas autobiográficas, análise quantitativa dos questionários e tratamento arquivístico de dados. Especialmente nas pesquisas de cunho empírico-teórica percebe-se a mescla da análise quantitativa e da análise qualitativa, com o intuito de interpretar os dados empíricos coletados.

\subsubsection{O nível metodológico}

$\mathrm{Na}$ metodologia assumida pelas teses fenomenológicas predominou o aspecto subjetivo, buscando um discurso de cunho descritivo, a partir "de dentro", e também um discurso compreensivo e interpretativo. Nas teses que fundamentaram-se em tendências pós-modernas, prevalece a diversidade de propostas, sendo que a maioria, num total de oito teses, seguiram o método objetivo, três trabalhos indicaram a confluência do quantitativo e do qualitativo, e outros três afirmaram utilizar a combinação do método objetivo e subjetivo, dois indicaram o método da complexidade e um indicou o método descrito. Nas teses marxistas constatou-se a predominância do método objetivo, na reconstrução histórica do objeto, na sua compreensão a partir do quadro teórico, na valorização do contexto histórico-social. Somente cinco pesquisas indicaram a presença de aspectos subjetivos no tratamento dos dados. De modo geral as teses marxistas tiveram uma orientação marcadamente dialética, perceptível no intuito dos autores em compreender os dados empíricos como parte do contexto histórico-social que os determinava, fazendo emergir os conflitos e as implicações sociais de cada objeto.

\subsubsection{O nível teórico}

No nível teórico observou-se a temática e as categorias utilizadas para abordá-las. Nas teses fenomenológicas as temáticas foram da criança, da capoeira e do negro, e as categorias teóricas mais utilizadas foram: fenômeno, compreensão, sentido, emancipação, reprodução, "desde dentro", cotidiano, vida privada. 
As teses que assumiram tendências pós-modernas como paradigma epistemológico abordaram temáticas diversas, classificadas em quatro grupos: aspectos institucionais, prática educacional, teorias educacionais e temas diversos (cibercultura, fotografia, artesanaria). As categorias teóricas mais utilizadas nestas pesquisas foram: intersubjetividade, complexidade, pós-modernidade, cotidianidade, multiculturalismo, representação, cultura urbana, relação público/privado, heterogeneidade, negatricidade, bricolagem, virtual, cibercultura, consenso, olhar, imagem, ficção, ciberespaço, alteridade, homogeneização cultural, educação digital, campo científico, legitimidade científica, emancipação social, dignidade dos excluídos, liberdade, cidadania, formação.

As diversas temáticas abordadas pelas 35 teses marxistas foram agrupadas nos seguintes blocos: ações educativas, educação e sociedade, instituições educacionais,aspectos institucionais, teorias educacionais e políticas educacionais. As categorias mais indicadas e utilizadas na interpretação dos dados empíricos foram (em ordem de frequência): trabalho, classes sociais, luta ou conflito de classes, contradição, alienação, práxis, totalidade, intelectual orgânico, neoliberalismo, propriedade privada, ideologia, dialética, mediação, emancipação, consciência de classe, indústria cultural, relações sociais de produção, concreto, habitus, autonomia, capitalismo, educação profissionalizante, capital econômico, capital cultural, burguesia, fetiche, mais-valia, Bildung, partido político, estética, trajetória, campo, formação integral, desenvolvimento tecnológico.

\subsubsection{O nível epistemológico}

O critério de cientificidade nas teses com fundamento fenomenológico foi definido com a categoria de dialética polissêmica, não unidirecional e não dogmática, e a verdade como sendo dada pelo aspecto vivencial da realidade pesquisada, numa totalidade aberta.

Na teses de fundamentação pós-moderna percebe-se uma diversidade de proposições teóricas, prevalecendo a postura de rejeição à racionalidade moderna, assentadas nas verdades absolutizadas e matematizadas, que devem ceder lugar para a subjetividade humana. Afirma-se o 
desmoronamento das verdades e certezas absolutas, defendendo que a verdade deve ser buscada na relação do singular para o singular, sendo construída nas relações da vida prática. Aponta-se a superação da ciência embasada no racionalismo e no positivismo, afirmando em seu lugar uma ciência da complexidade, que rompa com o pensamento linear, unitário e reducionista do paradigma da simplicidade.

Nas teses que assumiram o Marxismo como referencial teórico, o critério de cientificidade esteve alicerçado na relação dialética entre os diferentes aspectos da realidade pesquisada, visando detectar ideologias que rejeitam a noção de totalidade ou que negam o condicionamento ao caráter de classe. A verdade é sempre compreendida como histórica, pois o pensamento acompanha o movimento contraditório do real, e deve ser entendida a partir do contexto, porque é um processo multiplamente determinado. A ciência por excelência é a história, pois todo conhecimento é produzido socialmente, com fatos históricos carregados de contradições. Faz-se a crítica à ciência moderna porque seus avanços não foram capazes de libertar a humanidade de problemas que a vitimava, e também nega-se a pretensão de neutralidade por ela postulada. A ciência deve estar ligada à práxis, sendo um conhecimento que articule a dimensão prática com a dimensão teórica.

\subsubsection{Os pressupostos gnosiológicos}

Nas teses fundamentadas na Fenomenologia prevalece a primazia do sujeito, e considera-se a subjetividade do pesquisador como sendo essencial. Afirma-se que a dicotomia entre o sujeito e o objeto, com a tradicional submissão do sujeito ao objeto, é superada, e a facticidade agora é dada pelo ser-no-mundo.

Nas teses de fundamentação pós-moderna predominou a inferência do objeto como determinante do conhecimento, embora com variações na compreensão do objeto, desde o objeto virtualizado, passando pelo objeto descrito de maneira singular, até o objeto apreendido a partir de seu contexto histórico. Nas teses que afirmaram a interação entre o sujeito e o objeto, advoga-se a superação da dicotomia entre ambos em prol da 
intersubjetividade. E nas pesquisas que afirmam a predominância do sujeito, o conhecimento é definido a partir do olhar do pesquisador, que recorta e produz a realidade.

Já nas teses marxistas, com exceção de quatro pesquisas que assumiram a interação do sujeito e do objeto, prevaleceu a predominância do objeto na produção do conhecimento, destacando a importância do contexto histórico-social na compreensão do objeto pesquisado, o qual é resultado de múltiplas determinações, levando a uma unidade dialética entre realidade e conhecimento. Este é sempre condicionado pelo social e toda teoria não é uma produção neutra, mas uma prática relacionada ao contexto social no qual é produzida.

\subsubsection{Os pressupostos ontológicos}

$\mathrm{Na}$ análise epistemológica das teses foram identificados os pressupostos ontológicos, que também serão apresentados neste artigo de forma comparativa entre os três paradigmas epistemológicos identificados, utilizando expressões e definições contidas nas teses analisadas.

\section{A temporalidade}

A concepção de temporalidade presente nas teses de paradigma fenomenológico é a sincrônica, pois, apesar da história ser compreendida de forma dinâmica, a causa de seu movimento não é atribuída à luta de classes, mas sim à interação do homem com a realidade cotidiana.

A análise das teses pós-modernas, revelou uma equivalência entre a concepção sincrônica e diacrônica. Na visão diacrônica indica-se a história como palco de lutas políticas e ideológicas, mas seu movimento é visto como mudança na ótica de progresso, sem rupturas profundas ou revoluções. A concepção sincrônica variou desde a simples afirmação da história como sendo meramente factual até a compreensão singular e fragmentada, chegando a uma concepção acrônica, a qual defende a repetição e o cotidiano como oposição à ruptura, ao tempo e à história.

E nas teses marxistas, todas as pesquisas apresentaram uma concepção diacrônica, segundo a qual a realidade é dinâmica, sendo 
movimentada e transformada pela prática social, determinada pelo conflito de classes. Predominam as categorias de movimento e transformação, de relações dialéticas e contraditórias, de devir e de processualidade.

\section{A realidade}

Nas teses de fundamento fenomenológico a realidade é determinada por aquilo que o sujeito percebe e o mundo é o lugar de produção de sentido. Nas teses de fundamentação pós-moderna, a realidade é compreendida de forma diversa oscilando entre uma postura que a entende a partir de seus elementos imateriais até a compreensão de caráter crítico e materialista. Assim, o mundo é descrito como imagético, virtual e portanto, ficcional, e a realidade é vista em sua particularidade, sendo caracterizada pela sua pluralidade e heterogeneidade; numa compreensão mais crítica, a realidade é apresentada como sendo complexa e marcada por contradições sociais, mas as crises são sempre polissignificativas, levando a um desenvolvimento gradual, sem movimentos revolucionários; finalmente, em uma posição mais positivista, a realidade também é apresentada de modo funcional.

Nas teses com fundamentação marxista, a realidade foi definida como materialidade dialética, e concebida como uma totalidade multifacetária, enquanto síntese de múltiplas determinações. É essencialmente contraditória, marcada pela luta de classes e pelo conflito econômico, mas pode ser transformada e, nessa tarefa, o trabalho ocupa importante papel, pois ao modificar o mundo dos objetos, também pode originar uma nova objetividade.

\section{A sociedade}

$\mathrm{Na}$ descrição sobre a sociedade nas teses fenomenológicas aparecem categorias como classe social, dominação e transformação social, porém, sob o enfoque de diversidade de posições teóricas e de interesses de grupos antagônicos, e não a partir das relações sociais de produção. A própria transformação social não é apresentada de forma conflitiva, mas de forma descritiva, como parte integrante do processo histórico. 
Nas teses pós-modernas, a sociedade é vista de forma bastante diversificada, desde a sociedade determinada pelo virtual, até a sociedade marcadamente conflitiva. Entendida como virtual, é constituída por um sistema representacional, sendo essencialmente imagética, e os fenômenos sociais não são caracterizados pelas categorias de ordem nem de conflito, mas de complexidade e de heterogeneidade. A sociedade também é apresentada em algumas pesquisas de forma harmônica, democrática, em vista da qual o cidadão deve ser formado para que possa nela participar. Há também o entendimento da sociedade como sendo conflitiva, na qual os segmentos dominantes buscam a manutenção e a consolidação do poder, mas a proposta de superação permanece no nível individual e o foco da luta é deslocado das classes sociais para os novos movimentos organizados ou para o campo da cultura. Enfim, na maioria das pesquisas deste grupo, a sociedade é compreendida como palco de conflitos e marcada por desigualdades; porém, trata-se de uma percepção pontual e superficial dos inegáveis problemas sociais brasileiros, não sendo fruto de uma análise das estruturas de opressão a partir da divisão social do trabalho.

Em todas as teses fundamentadas no Marxismo, a sociedade é vista como sendo determinada pela materialidade do trabalho, conflitiva por estruturar-se em classes sociais e dialeticamente dinâmica. De modo geral a sociedade é apresentada como sendo formada a partir das relações do homem com a natureza, tornando-se a forma histórica de organização da atividade coletiva dos seres humanos, e especificamente a sociedade capitalista, é determinada pela divisão social do trabalho que gera a tensão entre a estrutura e a superestrutura e também é causa da alienação e da exploração de um indivíduo sobre o outro. A sociedade também é explicada a partir das relações entre os homens, relações concretas e contraditórias. Sendo históricas tais relações são passíveis de transformação e a sociedade está em constante mudança, determinada pelo devir histórico. O atual sistema democrático é entendido como regime político e arcabouço institucional que surgiram com a sociedade burguesa. 


\section{O homem}

Nas teses de fundamento fenomenológico o homem é definido como aquele que está-no-mundo, é-no-mundo, ou mesmo, está-com-o-mundo. Aparece um enfoque materialista, afirmando que a experiência individual está inserida em uma conjuntura que a influencia.

A antropologia subjacente às pesquisas que foram classificadas no grupo da pós-modernidade apresenta o homem como um ser fragmentado. Visto de forma plural, o ser humano se caracteriza por uma multideterminação de fatores, quais sejam, fatores sociais, econômicos, políticos, psíquicos. É possível perceber uma bricolagem de concepções antropológicas: o homem é agente produtor, mas isolado do seu contexto; não está inserido em uma classe social, mas situado no espaço e no tempo, e envolvido em relações, desejos e práticas marcadas pela paixão, pelo poder, pelas alianças, pelas mudanças e pelos intercâmbios; é definido em perspectiva liberal, capaz de gozar de direitos e contrair obrigações sociais, e também como um social e histórico, que se constrói no próprio ato de existir, existindo num mundo de e do trabalho.

As teses de fundamento marxista, de modo geral apresentam uma antropologia determinada pelas relações sociais de produção, a qual pode ser explicitada em três aspectos: o trabalho, a classe social, e a relação com a realidade. O ser do homem é definido a partir da sua relação com o trabalho, sendo este a base social de construção de seu ser e de sua consciência. É um ser social, tendo sua condição humana socialmente produzida a partir da relação com a classe a que pertence. E em sua relação com a realidade, aparecem duas concepções antropológicas: uma mais negativa, afirmando que o homem é um ser alienado, seja pela mais-valia, seja pela indústria cultural; e outra mais positiva, vendo homem a partir de seu potencial criativo, capaz de humanizar sua condição e de transformar o mundo, tendo como ideal antropológico o homem omnilateral.

\section{A educação}

A concepção de educação apresentada nas teses de referencial fenomenológico não tem um caráter positivo, seja porque é vista como uma 
área de conflito entre diferentes modelos de socialização, seja porque prevalece a concepção da escola como reprodutora das relações de opressão.

Nas pesquisas fundamentadas nas tendências pós-modernas, a educação foi compreendida de diferentes maneiras, desde a perspectiva da complexidade até a visão crítica. Sob a ótica da complexidade, a educação e a escola são vistos como aspectos de uma situação complexa ligada a questão do processo de afirmação social, e chega-se a ausência de referência à educação escolar, enfatizando a transmissão de valores por meio das práticas culturais. Outra concepção, de tendência subjetivista, afirma que educação é o processo social de construção de subjetividade e, mais que a transmissão de um saber e saber-fazer, é a experiência de um saber-ser e um saber-tornar-se. Algumas teses apresentaram a educação como caminho de ascensão social, seja no âmbito da cidadania, seja na aquisição de competências. E finalmente, identificou-se também uma dimensão crítica, a qual afirma como objetivo da educação favorecer a libertação do homem, porém sem uma associação explícita com o conflito de classes. A educação não é vista como um instrumento ideológico da classe dominante, e tem a tarefa de formar homens livres e autônomos, na busca de uma vida mais digna.

Também as teses de fundamentação marxista apresentaram posturas divergentes acerca do papel da educação e da escola, oscilando entre a concepção meramente reprodutora e o reconhecimento de seu papel emancipador. Identificou-se a concepção do marxismo clássico sobre educação e escola, de que ambas pertencem à superestrutura, são determinadas pela materialidade conflitiva das relações sociais, e não podem combater a desigualdade social, porque esta não é gerada no seu âmbito de atuação. Uma concepção intermediária defende que o processo educativo oscila entre caráter produtor e reprodutor, podendo tanto reproduzir as desigualdades sociais, adaptando e integrando o indivíduo ao capitalismo, quanto pode oferecer resistência, sendo um processo de construção de sujeitos críticos capazes de transformar o mundo e a si próprio. E em parte das teses reconhece-se a positividade da prática educacional, enquanto espaço para criar identidade e favorecer a 
humanização, com o papel de interpretar a realidade e de assumir compromisso com a prática emancipatória. No tocante a relação entre a Educação e o trabalho, predomina a crítica ao modelo neoliberal, a rejeição ao modelo das competências e a defesa da escola unitária e politécnica.

\subsubsection{O nível ético}

Por fim, a análise epistemológica verificou se os autores indicaram de modo explícito a aplicação de sua pesquisa em ações prática visando a transformação da realidade. Nas teses fenomenológicas, mesmo sendo um paradigma centrado na ação do sujeito compreendido individualmente, fezse referência às situações de dominação e a necessidade de transformação, mas sem apontar ações objetivas. Apesar das tendências pós-modernas favorecerem à despolitização e o esvaziamento da práxis, algumas teses deste paradigma apontaram questões sociais, e uma tese indicou ações concretas em favor dos povos indígenas da Amazônia.

Nas teses de fundamentação marxista, somente 12, o equivalente a $35 \%$ das pesquisas deste grupo, indicaram ações efetiva tendo em vista a transformação da realidade. Isso indica um distanciamento entre a teoria e a prática, que não deveria ocorrer neste paradigma, revelando uma lacuna na produção científica destas teses que assumiram o Marxismo como fundamentação teórica.

\subsection{Análise das referências ${ }^{2}$}

O resultado da coleta nas 55 teses analisadas foi de 4.227 registros de obras referenciadas, num total de 3.621 obras, sendo algumas referenciadas em várias teses e a maioria em apenas uma. Do total de obras utilizadas, 3.320 foram referenciadas em somente uma tese e 301 em mais que uma; destas, somente 21 obras foram referenciadas em 6 ou mais trabalhos. A Tabela 1 explicita essa relação entre a quantidade de obras e a quantidade de teses em que elas foram utilizadas.

2 É comum utilizar a expressão Análise das Citações, mas optamos em utilizar o termo Referência no sentido mais amplo, indicando a utilização da obra e do autor, reservando o termo citação para a análise específica. 
Tabela 1: Relação entre a quantidade de obras e a quantidade de teses em que

\begin{tabular}{c|c|c|c|c|c|c|c|c|c|c|c|c|c|c}
\hline $\begin{array}{c}\text { Quantidade } \\
\text { de teses em } \\
\text { que foram } \\
\text { citadas }\end{array}$ & 16 & 15 & 13 & 12 & 11 & 9 & 8 & 7 & 6 & 5 & 4 & 3 & 2 & 1 \\
\hline $\begin{array}{c}\text { Quantidade } \\
\text { de obras }\end{array}$ & 1 & 2 & 1 & 1 & 1 & 2 & 2 & 2 & 9 & 18 & 29 & 55 & 178 & 3.320 \\
\hline
\end{tabular}

\subsubsection{Obras mais utilizadas nas teses}

As obras que foram citadas em 6 ou mais teses, num total de 21 obras, destacando-se pela influência na produção do conhecimento em Educação, são as seguintes, como apresenta a Tabela 2:

Tabela 2: Obras que foram referenciadas em 6 ou mais teses.

\begin{tabular}{c|l}
\hline $\begin{array}{c}\text { Quantidade } \\
\text { de teses }\end{array}$ & \multicolumn{1}{c}{ Nome do autor e da obra } \\
\hline 16 & MARX, K.; ENGELS, F. A ideologia alemã (I - Feuerbach). \\
\hline 15 & MARX, K. Manuscritos econômico-filosóficos. \\
\hline 15 & MARX, K. O capital. ${ }^{2}$ \\
\hline 13 & KOSIK, K. Dialética do concreto. \\
\hline 9 & GRAMSCI, A. Os intelectuais e a organização da cultura ${ }^{4}$ \\
\hline 12 & $\begin{array}{l}\text { MANACORDA, M. A. História da educação: da Antiguidade } \\
\text { aos nossos dias. }\end{array}$ \\
\hline 11 & SAVIANI, D. Escola e democracia. \\
\hline 9 & $\begin{array}{l}\text { SAVIANI, D. Educação: do senso comum à consciência } \\
\text { filosófica. } \quad \text { primeiras }\end{array}$ \\
\hline 8 & GRAMSCI, A. Concepção dialética da história. \\
\hline 7 & $\begin{array}{l}\text { SAVIANI, D. Pedagogia histórico-crítica: } \\
\text { aproximações. } \quad\end{array}$ \\
\hline 7 & FRIGOTTO, G. Educação e crise do capitalismo real. \\
\hline
\end{tabular}

3 Devido às diferenças entre as diversas edições, consideramos na contagem, como sendo uma única obra, independente do Livro e do Volume.

4 Incluiu-se neste total também 4 referências da tradução feita pelo Prof. Dr. Paolo Nosella, do Caderno 12. 


\begin{tabular}{c|l}
\hline 6 & $\begin{array}{l}\text { ENGUITA, M. F. A face oculta da escola: educação e trabalho } \\
\text { no capitalismo. }\end{array}$ \\
\hline 6 & $\begin{array}{l}\text { FERREIRA, A. B. H. Novo dicionário Aurélio da língua } \\
\text { portuguesa. }\end{array}$ \\
\hline 6 & FRIGOTTO, G. A produtividade da Escola improdutiva. \\
\hline 6 & GRAMSCI, A. Maquiavel, a Política e o Estado Moderno. \\
\hline 6 & HARVEY, D. A condição pós-moderna. \\
\hline 6 & $\begin{array}{l}\text { HOBSBAWM, E. A era dos extremos (o breve século XX - } \\
\text { 1914-1991). }\end{array}$ \\
\hline 6 & MARX, K. Obras escolhida. V. 1. \\
\hline 6 & $\begin{array}{l}\text { SANTOS, B. de S. Pela mão de Alice: o social e o político na } \\
\text { pós-modernidade. }\end{array}$ \\
\hline 6 & $\begin{array}{l}\text { SAVIANI, D. A nova lei da educação: trajetória, limites e } \\
\text { perspectivas. }\end{array}$ \\
\hline
\end{tabular}

Destas obras mais referenciadas, quase todas foram aplicadas para fundamentar a pesquisa, sendo somente 5 utilizadas para apresentar alguma crítica ao pensamento do autor, as quais são: de Dermeval Saviani, receberam críticas as obras Escola e democracia; Pedagogia históricocrítica: primeiras aproximações; e Educação: do senso comum à consciência filosófica. Da autoria de Gaudêncio Frigotto, as obras Educação e crise do capitalismo real, e A produtividade da Escola improdutiva.

\subsubsection{Obras mais utilizadas em cada paradigma;}

As 3 teses que utilizaram o paradigma fenomenológico tiveram um total de 503 registros de referências, o que equivale a quase $12 \%$ do total. Representando pouco mais de 5\% das teses analisadas, apresentaram um total de referências superior a média. Enquanto a média geral foi de 77 registros por tese, neste grupo, a média foi de quase 168 registros em cada tese. Nos 503 registros foram identificadas 496 obras, sendo a grande maioria, 491 obras, utilizada em somente uma tese. As obras quer foram referenciadas em duas ou mais teses são: FREYRE, G. Casa Grande e Senzala; FREYRE, G. Sobrados e mucambos; BOURDIEU, P.; PASSERON, J-C. A reprodução: elementos para uma teoria do sistema de ensino; FREYRE, G. Ordem e progresso. Percebe-se a ausência de obras 
clássicas de fenomenologia e, as obras de autores ligados a esta corrente filosófica, como Marleau Ponty e Heidegger, figuram entre as referências, mas não receberam igual relevância.

As 17 teses que se fundamentaram em tendências pós-modernas tiveram um total de 1.431 registros de referências, o que equivale a cerca de um terço do total das referências registradas. Foram utilizadas 1.372 obras, sendo que a grande maioria, 1.325 obras, foram utilizadas em somente uma tese. As obras referenciadas em três ou quatro teses, e que se caracterizam como paradigmáticas nesse grupo de teses foram: MANACORDA, M. A. História da Educação; SANTOS, B. de S. Um discurso sobre as ciências; SAVIANI, D. Escola e democracia; COULON, A. Etnometodologia; KUHN, T. A estrutura das revoluções científicas; LYOTARD, J. F. A condição pós-moderna ${ }^{5}$; MIZUKAMI, M. G. N. Ensino: as abordagens do processo; SANTOS, B. de S. Pela mão de Alice; WARDE, M. J. O papel da pesquisa na pós-graduação em educação.

As 35 teses que utilizaram o paradigma epistemológico do Marxismo apresentaram um total de 2.293 registros de referências, o que representa pouco mais de $54 \%$ do total. Considerando que as teses deste grupo representam quase $64 \%$ do total, a quantidade de referências utilizadas foi menor que nos outros dois grupos. Este total de 2.293 registros foi constituído de 1.941 diferentes obras e, destas, 1.773 foram utilizadas somente em uma tese. As 10 obras mais referenciadas e que foram citadas em 7 ou mais teses são: MARX, K. O capital; MARX, K.; ENGELS, F. A ideologia alemã; MARX, K. Manuscritos econômico-filosóficos; KOSIK, K. Dialética do concreto; GRAMSCI, A. Os intelectuais e a organização da cultura; FRIGOTTO, G. Educação e crise do capitalismo real; GRAMSCI, A. Concepção dialética de história; SAVIANI, D. Pedagogia históricocrítica; MANACORDA, M. História da educação; SAVIANI, D. Educação: do senso comum à consciência filosófica.

\footnotetext{
${ }^{5}$ Em algumas teses, essa obra foi referenciada com o título $O$ pós-moderno. Sobre o nome desta obra, ver nota 4 no item 8.5.
} 


\subsubsection{Autores que foram mais referenciados}

A explicitação dos autores mais referenciados objetiva revelar a importância que determinados autores possuem no campo da pesquisa em Educação. O total de autores referenciados nas teses foi de 2.323. Para identificá-los o procedimento adotado foi de considerar como um registro cada obra utilizada em uma determinada tese, independente do número de citações feitas; e como um novo registro quando a mesma obra foi citada em teses diferentes. Igualmente foi considerado como um novo registro para o autor quando ele foi referenciado em obras de coautoria. A Tabela 3 apresenta os 20 autores mais utilizados:

Tabela 3 - Os 20 autores mais referenciados

\begin{tabular}{|c|c|c|}
\hline $\begin{array}{l}\text { Número de vezes } \\
\text { que foi referenciado }\end{array}$ & $\begin{array}{l}\text { Número de teses em } \\
\text { que autor foi utilizado }\end{array}$ & Autores referenciados \\
\hline 59 & 29 & Dermeval Saviani \\
\hline 49 & 22 & Karl Marx \\
\hline 48 & 26 & Antonio Gramsci \\
\hline 38 & 14 & Pierre Bourdieu \\
\hline 30 & 13 & Gaudêncio Frigotto \\
\hline 29 & 15 & Florestan Fernandes \\
\hline 26 & 13 & Luiz Antonio Cunha \\
\hline 26 & 19 & $\begin{array}{lll}\text { Karl Marx; } & \text { Friedrich } \\
\text { Engels } & & \\
\end{array}$ \\
\hline 25 & 11 & Norberto Bobbio \\
\hline 24 & 12 & Octavio Ianni \\
\hline 22 & 15 & Marilena Chauí \\
\hline 22 & 14 & Eric J. Hobsbawn \\
\hline 22 & 06 & Darci Ribeiro \\
\hline 21 & 02 & Matthew Lipman \\
\hline 20 & 15 & Paolo Nosella \\
\hline 19 & 01 & Jacques Ardoino \\
\hline 18 & 06 & Jüngen Habermas \\
\hline 18 & 17 & Mario A. Manacorda \\
\hline 17 & 06 & Theodor L. Adorno \\
\hline
\end{tabular}




\begin{tabular}{l|l|l}
\hline 16 & 05 & Pablo Gentili \\
\hline
\end{tabular}

Os dados indicam a influência do pensamento de Saviani na produção científica do PPGE-UFSCar. Isso pode ser entendido tanto internamente, por sua presença na criação do Programa, quanto externamente, pela importância deste autor no campo da Educação. Também destaca-se a influência do pensamento de Marx, pois, considerando o conjunto das referências em coautoria com Engels, verifica-se 75 vezes em que seu pensamento foi utilizado.

A intersecção de dados na Tabela 3 revela que, determinados autores, embora apareçam com um menor número de referências, tiveram uma influência maior na fundamentação teórica das pesquisas, se comparados com autores que apresentaram um maior número de referências. Pode-se verificar isso na comparação dos dados referentes a M. Lipman e P. Nosella, indicando que este teve uma influência maior, pois foi utilizado em 15 pesquisas, enquanto o primeiro foi utilizado em somente duas. A mesma relação pode ser feita entre J. Ardoino e Manacorda; pois o primeiro foi referenciado em uma única pesquisa, a qual aborda a questão da multirreferencialidade a partir do pensamento daquele autor, enquanto Manacorda foi referenciado em 17 teses.

\subsubsection{Autores mais referenciados em cada paradigma}

As 3 teses que se fundamentaram teoricamente na Fenomenologia utilizaram o pensamento de 344 autores. Os que foram referenciados 6 ou mais vezes foram: Gilberto Freyre, Antonio Sérgio Alfredo Guimarães, Octávio Ianni, Muniz Sodré, Thales de Azevedo, Edison Carneiro.

As 17 teses que se fundamentaram em tendências pós-modernas utilizaram o pensamento de 972 autores. A grande maioria, 781 autores, foram referenciados apenas uma vez. Os que foram mais referenciados 9 ou mais vezes foram: Jacques Ardoino, Darci Ribeiro, Dermeval Saviani, Jüngen Habermas, Jean-Jacques Rousseau, Joaquim Gonçalves Barbosa, Norberto Bobbio, Matthew Lipman, Boaventura de Souza Santos, Michel Foucault, Edgar Morin, Anísio Teixeira. 
E as 35 teses que assumiram o Marxismo como referencial teórico fizeram uso do pensamento de 1.329 autores, sendo que destes, 1.056 foram referenciados apenas uma vez. Os que foram referenciados em 10 ou mais teses foram: Karl Marx, Dermeval Saviani, Antonio Gramsci, Gaudêncio Frigotto, Pierre Bourdieu, Karl Marx e Friedrich Engels, Florestan Fernandes, Eric J. Hobsbawn, Luiz Antonio Cunha, Pablo Gentili, Paolo Nosella, Theodor Ludwig Adorno, Octávio Ianni, Newton Duarte, Norberto Bobbio, Georg Lukács, Mario A. Manacorda, Marilena Chauí, Acácia Kuenzer, Karel Kosik, Lev S. Vygotsky.

\subsubsection{Obras e autores utilizados na fundamentação do referencial teórico}

Do conjunto total das 3.621 obras citadas, apenas 301, o que equivale a pouco mais de $10 \%$, foram utilizadas para fundamentar especificamente o referencial teórico. As obras que foram utilizadas para este fim, em 3 ou mais teses estão elencadas na Tabela 4:

Tabela 4 - Obras utilizadas para fundamentar o referencial teórico em 3 ou mais teses

\begin{tabular}{c|l}
\hline Número de teses & \multicolumn{1}{|c}{$\begin{array}{c}\text { Obras utilizadas para fundamentar o referencial } \\
\text { teórico }\end{array}$} \\
\hline 10 & MARX, K.; ENGELS, F. A ideologia alemã. \\
\hline 9 & MARX, K. O Capital: crítica da economia política. \\
\hline 8 & KOSIK, K. Dialética do concreto. \\
\hline 7 & MARX, K. Manuscritos econômicos e filosóficos. \\
\hline 5 & GRAMSCI, A. Concepção dialética da história. \\
\hline 5 & $\begin{array}{l}\text { GRAMSCI, A. Maquiavel: a política e o Estado } \\
\text { moderno. }\end{array}$ \\
\hline 5 & $\begin{array}{l}\text { GRAMSCI, A. Os intelectuais e a organização da } \\
\text { cultura. } \quad \text { BOBBIO, N. Liberalismo e democracia. }\end{array}$ \\
\hline 3 & BOURDIEU, P. Questões de sociologia. \\
\hline 3 & LUKÁCS, G. Ontologia do ser social. \\
\hline 3 & MARX, K. Para a crítica da economia política. \\
\hline 3 & $\begin{array}{l}\text { SOUZA SANTOS, B. Um discurso sobre as } \\
\text { ciências. }\end{array}$ \\
\hline
\end{tabular}




\subsection{Análise das citações}

O total de citações diretas e indiretas registradas foi de 13.393, numa média de 243 citações por tese. Nesta análise foi considerada como citação quando o autor da tese citou direta ou indiretamente um texto, indicando o número da página. Não foi considerado como citação a simples indicação de uma obra no decorrer do texto por ser pertinente ao assunto tratado, ou à qual o autor se reportou em sua pesquisa, mas sem a indicar a página. E quando uma determinada obra foi citada em apud, foi considerada a obra da qual foi retirada a citação, e não a obra original. Não foram consideradas as citações provenientes das fontes primárias, como legislação, documentos pesquisados, entrevistas, notícias de jornais da época.

\subsubsection{Obras mais citadas}

Considerando as 13.393 citações em relação com as 3.621 obras referenciadas, verificou-se a média de 3,7 citações para cada obra. As 100 obras mais citadas, equivalente a cerca de 2,8\% do total, tiveram 3.066 citações, o que representa quase $23 \%$ do total. Isso revela que, enquanto algumas obras foram citadas muitas vezes, um grande número de obras foram citadas apenas uma ou duas vezes. A Tabela 5 apresenta as 15 obras que foram mais citadas, em duas teses ou mais.

Tabela 5 - Obras mais citadas nas teses

\begin{tabular}{c|c|l}
\hline $\begin{array}{c}\text { Número } \\
\text { de } \\
\text { citações }\end{array}$ & $\begin{array}{c}\text { Teses } \\
\text { em que } \\
\text { foram } \\
\text { citadas }\end{array}$ & \multicolumn{1}{|c}{ Obra citada } \\
\hline 69 & 2 & $\begin{array}{l}\text { ADORNO, T. W.; HORKEIMER, M. Dialética do } \\
\text { esclarecimento. }\end{array}$ \\
\hline 66 & 11 & MARX, K. O Capital: crítica da economia política. \\
\hline 64 & 10 & SAVIANI, D. Escola e democracia. \\
\hline 52 & 2 & LIPMAN, M. O pensar na educação. \\
\hline 52 & 16 & $\begin{array}{l}\text { MARX, K.; ENGELS, F. A idelogia alemã (I - } \\
\text { Feuerbach). }\end{array}$ \\
\hline
\end{tabular}




\begin{tabular}{c|c|l}
\hline 49 & 13 & KOSIK, K. A dialética do concreto. \\
\hline 48 & 2 & VYGOTSKY, L. S. Obras escolhidas (v. 1 e 2). \\
\hline 47 & 7 & $\begin{array}{l}\text { FRIGOTTO, G. Educação e a crise do capitalismo } \\
\text { real. }\end{array}$ \\
\hline 47 & 7 & $\begin{array}{l}\text { SAVIANI, D. Pedagogia histórico-crítica: primeiras } \\
\text { aproximações. }\end{array}$ \\
\hline 46 & 11 & MARX, K. Manuscritos econômico-filosóficos. \\
\hline 44 & 4 & DELORS, J. (org.) Educação: um tesouro a descobrir. \\
\hline 44 & 3 & HELLER, A. Sociologia de la vida cotidiana. \\
\hline 43 & 4 & DUARTE, N. A individualidade para-si. \\
\hline 43 & 5 & LEONTIEV, A. N. O desenvolvimento do psiquismo. \\
\hline 42 & 5 & SMITH, A. A riqueza das nações. \\
\hline
\end{tabular}

Percebe-se que autores como Adorno e Horkeimer, Lipman e Vygotsky, tiveram obras que receberam um elevado número de citações, porém em duas teses apenas; revelando que o alto índice de citações não significa um campo ampliado de aplicação da obra. Já autores como Marx, Engels, Saviani, Kosik e Frigotto tiveram obras com um número significativo de citações em diversas teses, indicando que suas obras exercerem relevada influência na produção científica.

\subsubsection{Autores mais citados}

Com relação aos autores mais citados, foram consideradas as citações feitas de todas as obras referenciadas, em todas as teses. A Tabela 7 apresenta os 15 autores que foram mais citados, juntamente com a quantidade de obras e o número de teses em que foram citadas:

Tabela 7 - Autores mais citados nas teses

\begin{tabular}{l|c|c|c}
\hline \multicolumn{1}{c|}{ Autores citados } & $\begin{array}{c}\text { Número de } \\
\text { citações }\end{array}$ & $\begin{array}{c}\text { Número de } \\
\text { obras citadas }\end{array}$ & $\begin{array}{c}\text { Número } \\
\text { de teses }\end{array}$ \\
\hline Jean Jacques ROUSSEAU & 274 & 13 & 4 \\
\hline Dermeval SAVIANI & 250 & 22 & 29 \\
\hline Álvaro VIEIRA PINTO & 202 & 9 & 4 \\
\hline Antônio GRAMSCI & 185 & 17 & 26 \\
\hline
\end{tabular}




\begin{tabular}{l|c|c|c}
\hline Karl MARX & 166 & 14 & 22 \\
\hline Matthew LIPMAN & 133 & 19 & 2 \\
\hline Gaudêncio FRIGOTTO & 131 & 17 & 13 \\
\hline Lev S. VYGOTSKY & 108 & 7 & 7 \\
\hline Newton DUARTE & 107 & 7 & 7 \\
\hline Pierre BOURDIEU & 102 & 19 & 14 \\
\hline Jacques ARDOINO & 95 & 17 & 1 \\
\hline Theodor ADORNO & 91 & 11 & 7 \\
\hline Pierre LÉVY & 84 & 7 & 1 \\
\hline Luiz Antonio CUNHA & 81 & 18 & 13 \\
\hline Darcy RIBEIRO & 73 & 18 & 6 \\
\hline
\end{tabular}

Para melhor compreensão desses dados, vale ressaltar que Rousseau, Álvaro Veira Pinto, Lipman e Ardoino foram objeto específico de pesquisa, o que justifica o grande número de citações. Já Pierre Lévy, foi citado para analisar a relação entre a educação e a cibercultura, mas somente em uma tese. Saviani e Frigotto, além de serem citados em diversas teses, foram objeto de crítica em uma tese, o que também explica o grande número de citações. Os demais autores tiveram um número destacável de citações em diferentes teses, o que revela sua relevante importância na fundamentação teórica da pesquisa em Educação.

\subsubsection{As obras que foram criticadas}

Com relação à finalidade das citações, um número pequeno de teses estabeleceu alguma crítica à teoria citada, com exceção daqueles trabalhos que explicitavam o propósito de posicionar-se criticamente frente a uma determinada teoria. Verificou-se que 107 obras foram citadas para receber alguma forma de crítica. Destas, 101 foram criticadas em apenas uma tese, enquanto seis receberam críticas em mais que uma tese, como mostra a Tabela 6: 
Tabela 6 - Obras que receberam críticas em mais que uma tese

\begin{tabular}{c|l}
\hline Número de teses & \multicolumn{1}{|c}{ Obras que foram criticadas } \\
\hline 3 & DELORS, J. et al. Educação: um tesouro a descobrir. \\
\hline 3 & HAYEK, F. A. O caminho da servidão. \\
\hline 3 & SAVIANI, D. Escola e democracia. \\
\hline 3 & SMITH, A. A riqueza das nações. \\
\hline 2 & DURKHEIM, E. As regras do método sociológico. \\
\hline 2 & FRIEDMAN, M. Capitalismo e liberdade. \\
\hline 2 & $\begin{array}{l}\text { SAVIANI, D. Pedagogia Histórico-crítica: primeiras } \\
\text { aproximações. }\end{array}$ \\
\hline
\end{tabular}

\subsubsection{Tipos de documentos citados}

$\mathrm{Na}$ identificação do tipo do documento citado, foram considerados cinco grupos: livros (incluindo capítulos de coletâneas), artigos de periódicos científicos, teses e dissertações (incluindo Teses de Livre Docência e de concurso para Professor Titular), fontes da internet e outros (artigos publicados em jornais e revistas não científicas, resultados de congressos, anais, palestras, aulas, textos não publicados, CDs e músicas). O resultado foi a predominância, mais de $73 \%$, do uso de livros, seguido do uso de artigos de periódicos científicos, como mostra o Figura 7:

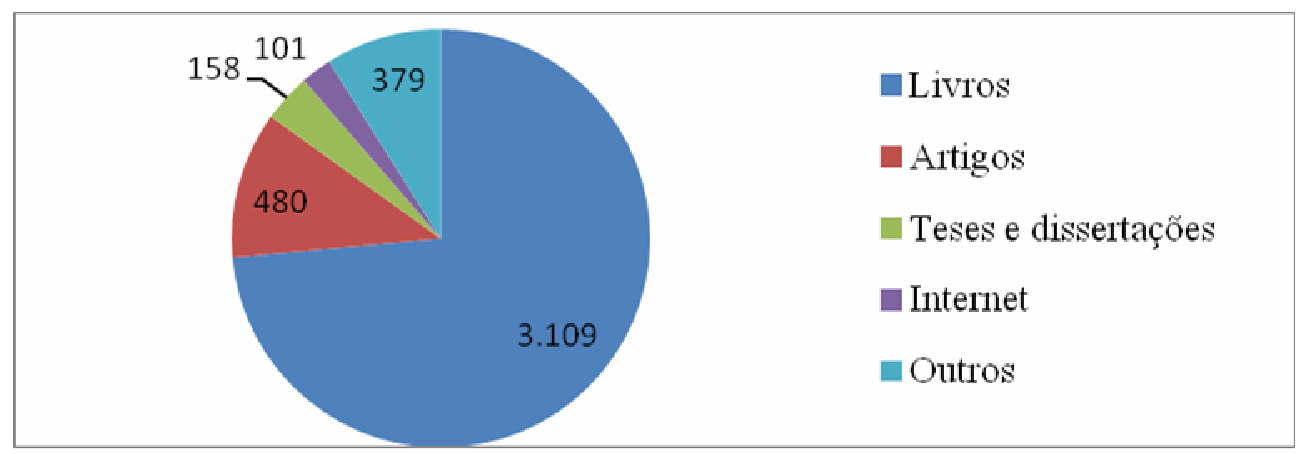

Figura 7 - Tipos de documentos citados 


\subsection{A contribuição dos orientadores}

O resultado da análise bibliométrica e epistemológica das teses, foi ampliado a partir das considerações apresentadas nos questionários respondidos por oito docentes orientadores e complementadas com os dados obtidos na leitura das principais obras, artigos e livros de todos os 13 docentes orientadores.

\subsubsection{O referencial teórico dos orientadores}

Com relação ao referencial teórico assumido pelos docentes no período de suas orientações no PPGE, verificou-se a predominância do Marxismo, como mostra a Figura 8:

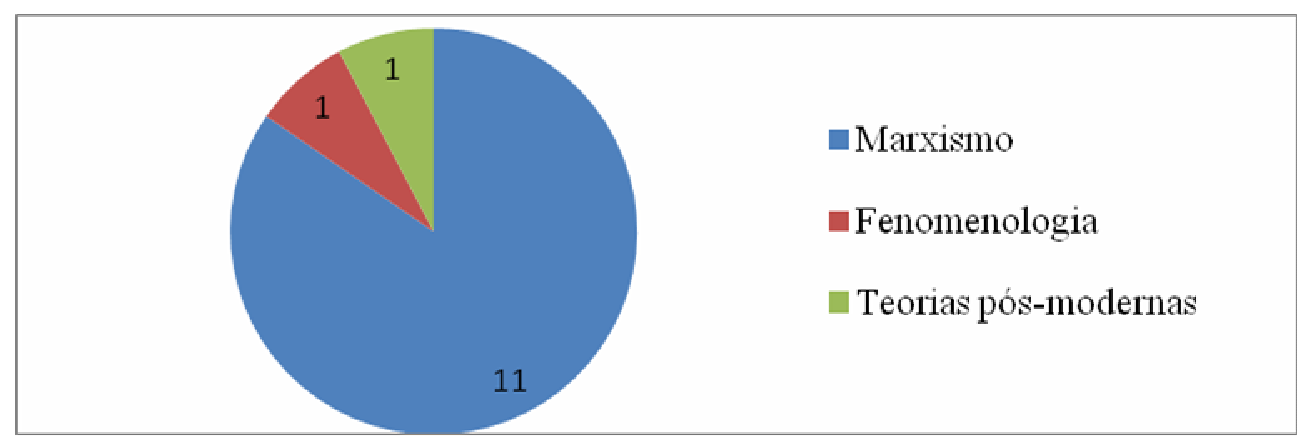

Figura 8 - Referencial teórico dos orientadores, agrupados nos paradigmas epistemológicos

Fonte: Questionários e obras (artigos e livros) dos docentes

Seguindo o procedimento realizado anteriormente com as teses, buscou-se detectar as diferentes nuances teóricas entre os docentes que indicaram o Marxismo como referencial teórico assumido, como mostra a Figura 9: 


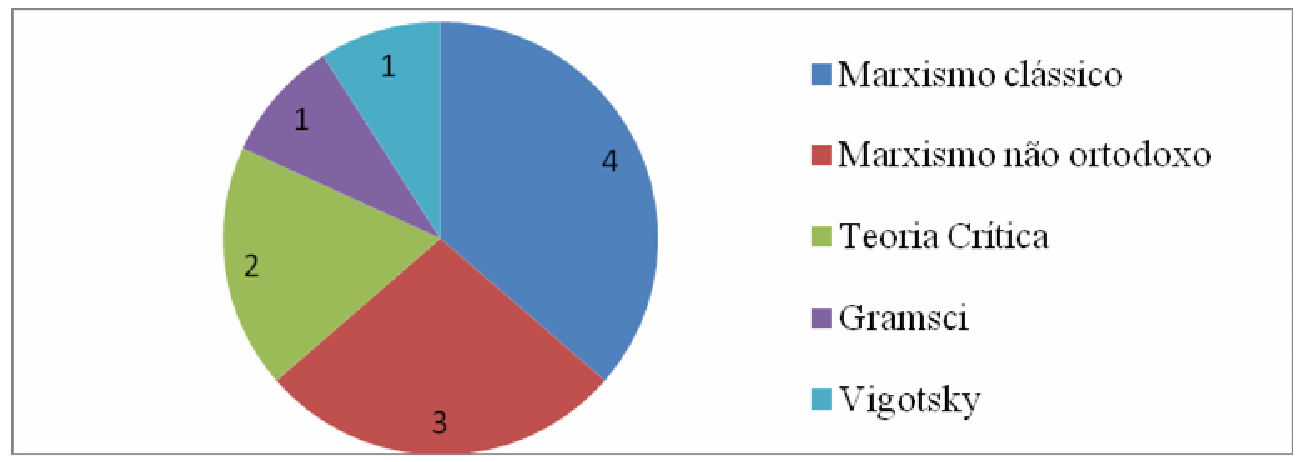

Figura 9 - Classificação dos orientadores segundo as diferentes concepções de Materialismo Histórico Dialético

Fonte: Questionários e obras (artigos e livros) dos docentes

Como observado nas teses, também na produção científica dos docentes orientadores o Marxismo não pode ser considerado como um bloco monomórfico, mas um diversificado leque de olhares teóricos, tendo em comum os mesmos fundamentos do método marxista.

Ao serem inquiridos sobre uma possível mudança do referencial teórico assumido no início das orientações no Doutorado do PPGE, todos afirmaram que conservaram o mesmo referencial. Entre eles, quatro destacaram que houve um aprofundamento, ou depuração teórica ou ampliação com relação ao referencial assumido inicialmente.

\subsubsection{A relação orientador-orientando na escolha do referencial teórico}

Com relação à influência que o orientador exerce sobre o seu orientando na escolha do referencial teórico para a pesquisa, embora todos tenham manifestado concordância de que existe tal influência, as respostas dos docentes não foram unânimes, variando desde a convicção de que tal influência é inevitável, passando pela compreensão de que é uma influência mútua, até a ideia de que é relativa, pois depende da livre escolha do aluno.

Sobre tal questão, obtivemos nove respostas, sendo oito dos questionários e uma de uma entrevista publicada pelo docente. As respostas foram classificadas em dois grupos: o primeiro, no qual a influência é pequena ou relativa, e até mesmo mútua, porque se reconhece a autonomia do orientando, sendo constatada quatro respostas; e um segundo grupo, com a resposta de cinco docentes, defendendo a ideia de que a influência é 
grande e inevitável, seja pela presença marcante do orientador na área da pesquisa, seja pela própria estrutura da seleção e da produção científica na pós-graduação.

\section{Notas conclusivas}

A análise bibliométrica revelou características peculiares do curso de Doutorado do PPGE-UFSCar: a consolidação da pesquisa, a partir da constância no número de ingressantes e de defesas por ano; a abertura para diferentes concepções teóricas dos docentes; a acolhida de pesquisadores de outras instituições e de outras regiões do país; a abertura à diversidade na formação dos pesquisadores, tanto na graduação, como no Mestrado; a ampla variedade de temas pesquisados; a atuação dos Doutores formados, de forma majoritária na atividade acadêmica, em IES de diferentes regiões do país.

O resultado da análise epistemológica revelou que o Marxismo, enquanto referencial teórico, preponderou nas pesquisas realizadas no Doutorado do PPGE-UFSCar, nos primeiro 15 anos de sua produção científica, representando mais de $60 \%$ das teses. Entretanto, o uso desse referencial teórico não ocorreu de modo monomórfico, mas reproduziu as diferentes nuances teóricas que o Marxismo adquiriu no decorrer no século XX. Também mostrou que o PPGE-UFSCar não permaneceu uma ilha, isolado do contexto mais amplo, sendo influenciado pelas tendências ditas pós-modernas. As 17 teses classificadas neste grupo revelam a crescente presença dessa tendência metodológica na pesquisa do Programa.

Como entender essa permanência do Marxismo como referencial teórico predominante no PPGE-UFSCar no período da pesquisa, dentro de um contexto histórico-social tão avesso às teorias marxistas, mesmo partilhando espaço acadêmico com as tendências pós-modernas?

Inicialmente, isso é compreensível a partir do atual contexto históricosocial, no qual as estruturas capitalistas de dominação e opressão não apenas permanecem, mas se tornaram mais incisivas. Ora, enquanto permanecerem tais estruturas capitalistas de exploração do trabalho e de acumulação de 
capital, o Marxismo será uma teoria imprescindível para compreensão dessa realidade e possibilidade de mudança.

Outro aspecto que elucida a permanência do Marxismo como referencial teórico no PPGE-UFSCar refere-se a postura teórica e prática dos orientadores e sua luta de resistência às tendências pós-modernas, apesar do contexto cultural não favorável. Essa atividade de militância dos intelectuais marxistas não se limita ao PPGE, mas é uma luta conjunta com outros grupos de intelectuais, como relatado nos questionários, sobre a parceria com o Grupo HISTEDBR da UNICAMP, e em consonância com a reação teórica ao chamado "giro linguístico".

Como verificado na análise do nível ético, observando as propostas apresentadas visando a transformação da realidade, a atual organização política e, ainda mais a ideologia pós-moderna de exacerbada fragmentação do real, dificultam uma afirmação incisiva de um caminho revolucionário, fazendo permanecer o impasse entre o teórico e o prático. Apesar desse cenário não efetivamente favorável a contribuição que este estudo almeja oferecer para a efetiva transformação da sociedade é a defesa sempre mais intensa da profundidade teórica que deve permear o processo de produção do conhecimento e o processo de formação, nos diferentes níveis da Educação. É o desafio que permanece para todos os pesquisadores em Educação que não aceitam a atual realidade de exclusão social e de fragmentação do real: calcar os pés no chão da vida e, com o tesouro teórico produzido até então, vislumbrar e dar passos para concretizar uma nova realidade possível.

\section{Referências}

AMADEO, Javier. Mapeando o marxismo. In: BORON, Atilio A.; AMADEO, Javier; GONZÁLEZ, Sabrina (Orgs.). A teoria marxista hoje: problemas e perspectivas. SP: CLACSO/Expressão Popular, 2006.

ANDERSON, Perry. Considerações sobre o marxismo ocidental; Nas trilhas do materialismo bistórico. SP: Boitempo Editorial, 2004

AZEVEDO, Fernando de. Na pesquisa das raízes de uma instituição. Revista Brasileira de Estudos Pedagógicos, Rio de Janeiro, v. 42, n. 95, p. 18-26, jul./set. 1964. 
BRASIL. Conselho Federal de Educação. Parecer CFE no 977/65. 1965. In: Guido Ivan de Carvalho (seleção, organização e notas). Ensino superior. legislação e jurisprudência. SP: Ed. Revista dos Tribunais, v. III, 1975, p. 123 148.

BRASIL. Conselho Nacional de Pós-Graduação. I PNPG - Plano Nacional de Pós-Graduação. In: BRASIL. Ministério da Educação. Plano Nacional de PósGraduação - PNPG 2005-2010. Ministério da Educação. Brasília: CAPES, 2005.

DEMO, Pedro. Metodologia cientifica em ciências sociais. 3. ed rev. e ampl. SP: Atlas, 2009

GATTI. Implicações e perspectivas da pesquisa educacional no Brasil contemporâneo. Cadernos de Pesquisa, n. 113, p. 65-81, julho/2001.

GOERGEN, Pedro. Pesquisa em educação, sua função crítica. Educação e sociedade. São Paulo, (9), p. 65-96, 1981.Habermas (1980

HABERMAS, Jüngen. Conhecimento e interesse. In: BENJAMIN, Walter, et al. Textos escolhidos. SP: Abril Cultural, p. 301-312, 1980 (Coleção Os Pensadores)

HABERMAS, Jüngen. Modernidade, um projeto inacabado. In: ARANTES, Otília B. Fiori; ARANTES, Paulo Eduardo. Um ponto cego no projeto moderno de Jürgen Habermas. SP: Brasiliense, p. 99-123, 1992.

HOBSBAWM, E. Era dos extremos: o breve século XX (1914-1991). 2. ed. SP: Companhia das Letras, 2009.

KUENZER, Acácia Z.; MORAES, Maria Célia M. de. Temas e tramas na pósgraduação em educação. Educação \& Sociedade, vol. 26, n. 93, p. 1341-1362, set./dez. 2005.

LIMA, Paulo Gomes. Tendências paradigmáticas na pesquisa educacional. SP: Amil, 2003.

LOURENÇO FILHO, Manuel Bergstrom. Antecedentes e primeiros tempos do INEP. Revista Brasileira de Estudos Pedagógicos, Rio de Janeiro, v. 42, n. 95, p. 8-17, jul./set. 1964.

LYOTARD, Jean-François. O pós-moderno. 4. ed. RJ: José Olympio, 1993.

MARX, Karl. Teses contra Feuerbach. In: . Os pensadores. $2^{\mathrm{a}}$ ed. SP: Abril Cultural, 1978.

MARX, Karl. Manuscritos Econômico-filosóficos. SP: Martin Claret, 2004

NOSELLA, Paolo; BUFFA, Ester. Instituições escolares: por que e como pesquisar. Campinas-SP: Alínea, 2009. 
PROGRAMA DE PÓS-GRADUAÇÃO EM EDUCAÇÃO - UFSCAR. PPGE 30 anos: fazendo história. São Carlos: Gráfica e Editora Compacta, 2007.

SÁNCHEZ GAMBOA, Silvio Ancízar. O giro ontológico: o resgate do real, independente da consciência e da linguagem. In: CHAVES-GAMBOA, M.; SANCHEZ GAMBOA, S. (Orgs.) Teorias e pesquisas em educação: os pósmodernismo. Maceió: EDUFAL, 2011

SÁNCHEZ GAMBOA, Silvio Ancízar. Pesquisa em educação: métodos e epistemologias. 2. ed. Chapecó-SC: Argos, 2012.

SAVIANI, Dermeval. História das idéias pedagógicas no Brasil. 2. ed. rev. e ampl. Campinas-SP: Autores Associados, 2008.

SAVIANI, Dermeval; GOLDBERG, Maria Amélia. Universidade Federal de São Carlos: mais um programa de pós-graduação em Educação?. Cadernos de Pesquisa. n. 16. São Paulo: Fundação Carlos Chagas, 1976.

SUCUPIRA, Newton. Antecedentes e primórdios da pós-graduação. Fórum Educacional, Rio de Janeiro, Fundação Getúlio Vargas, ano 4, nº 4, out.-dez., p. 3-18, 1980.

UFSCar. CECH - Centro de Educação e Ciências Humanas. PPGE - Programa de Pós-Graduação em Educação. Projeto de Doutorado em Educação. São Carlos, 1990. 